David Bargiela, MBBS

Patrick Yu-Wai-Man,

FRCOphth

Michael Keogh, MRCP

Rita Horvath, MD

Patrick F. Chinnery,

FRCP, FMedSci

Correspondence to

Prof. Chinnery:

patrick.chinnery@ncl.ac.uk

Editorial, page 1191

Supplemental data at Neurology.org

\title{
Prevalence of neurogenetic disorders in the North of England \\ OPEN
}

ABSTRACT

Objective: Genetic disorders enter the differential diagnosis of common neurologic diseases, but their overall prevalence is not known. We set out to determine their minimum prevalence.

Methods: Meta-analysis of epidemiologic data gathered from the same geographic region in the North of England.

Results: Monogenic neurologic disorders affect at least 90.9/100,000 (95\% confidence interval 87.6-94.3), or 1 in 1,100 of the population in Northern England.

Conclusion: As a group, neurogenetic disorders are not rare. These findings have implications for clinical service delivery. Neurology ${ }^{\circledR} 2015 ; 85: 1195-1201$

\section{GLOSSARY}

ADCA = autosomal dominant cerebellar ataxia; $\mathbf{A L S}=$ amyotrophic lateral sclerosis; $\mathbf{A R C A}=$ autosomal recessive cerebellar ataxia; $\mathbf{C l}=$ confidence interval; $\mathbf{C M T}=$ Charcot-Marie-Tooth; $\mathbf{D O A}=$ dominant optic atrophy; $\mathbf{H D}=$ Huntington disease; HNPP = hereditary neuropathy with liability to pressure palsy; HSP = hereditary spastic paraparesis; LHON = Leber hereditary optic neuropathy; $\mathbf{m t D N A}=$ mitochondrial DNA.

Recent advances in molecular diagnostics have expanded our understanding of the heritable basis of neurologic disease. The possibility of a highly penetrant mutation in a single gene enters the differential diagnosis of the most common neurologic disorders. If the inherited disorder presents late in life, or has a reduced penetrance, then there may be no affected relatives, so the absence of a family history does not preclude a genetic diagnosis. The widespread availability of inexpensive DNA tests has made it easier than ever to reach a molecular diagnosis in a patient with a suspected neurogenetic disorder, but the overall prevalence of these diseases has not been established. Herein, we present the results of a systematic review of neurogenetic disorders in the North of England, where the stable population has provided an ideal substrate for genetic epidemiology. ${ }^{1}$

METHODS We reviewed the reported prevalence of neurogenetic disorders, here defined as neurologic conditions known to be caused by highly penetrant mutations in a single gene (so-called "monogenic" or "single gene" disorders). We did not include data on common neurologic conditions, such as Alzheimer disease, Parkinson disease, motor neuron disease (amyotrophic lateral sclerosis [ALS]), or inherited dystonias, in which only a minority of cases are caused by a single highly penetrant gene defect, although their likely contribution is discussed later in the article.

A systematic literature review was undertaken by searching PubMed (MEDLINE) listings from January 1966 to April 2015 for relevant articles using the following terms: "ataxia," "neuropathy," "muscle disease," "myopathy," "dystrophy," "Huntington," "mitochondrial," "optic atrophy," or "hereditary spastic paraparesis" combined with the terms "epidemiology," "prevalence," or "incidence." There was no language restriction. The final reference list was generated on the basis of relevance to the topics covered in this review. Priority was given to studies based on a molecular genetic diagnosis rather than those based on clinical or biochemical criteria alone. Articles containing disease prevalence statistics for the North of England (see the figure for region definition) were included. The minimum point prevalence for each disorder was calculated using live affected cases and UK Office for National Statistics' population estimates for the North of England (appendix e-1 on the Neurology ${ }^{\circledR}$ Web site at Neurology.org) for the precise census date in each study. ${ }^{2}$ Exact $95 \%$ confidence intervals (CIs) were calculated by the Clopper-Pearson method.

RESULTS The systematic review identified the most up-to-date published prevalence data for the majority of neurogenetic disorders from the North of England between 1966 and 2015 (table). For hereditary spastic paraparesis (HSP), there were no published data from the United Kingdom and so we calculated a prevalence

From the Institute of Genetic Medicine, Newcastle University, Newcastle upon Tyne, UK.

Go to Neurology.org for full disclosures. Funding information and disclosures deemed relevant by the authors, if any, are provided at the end of the article. The Article Processing Charge was paid by The Wellcome Trust.

This is an open access article distributed under the terms of the Creative Commons Attribution License 4.0 (CC BY), which permits unrestricted use, distribution, and reproduction in any medium, provided the original work is properly cited. 


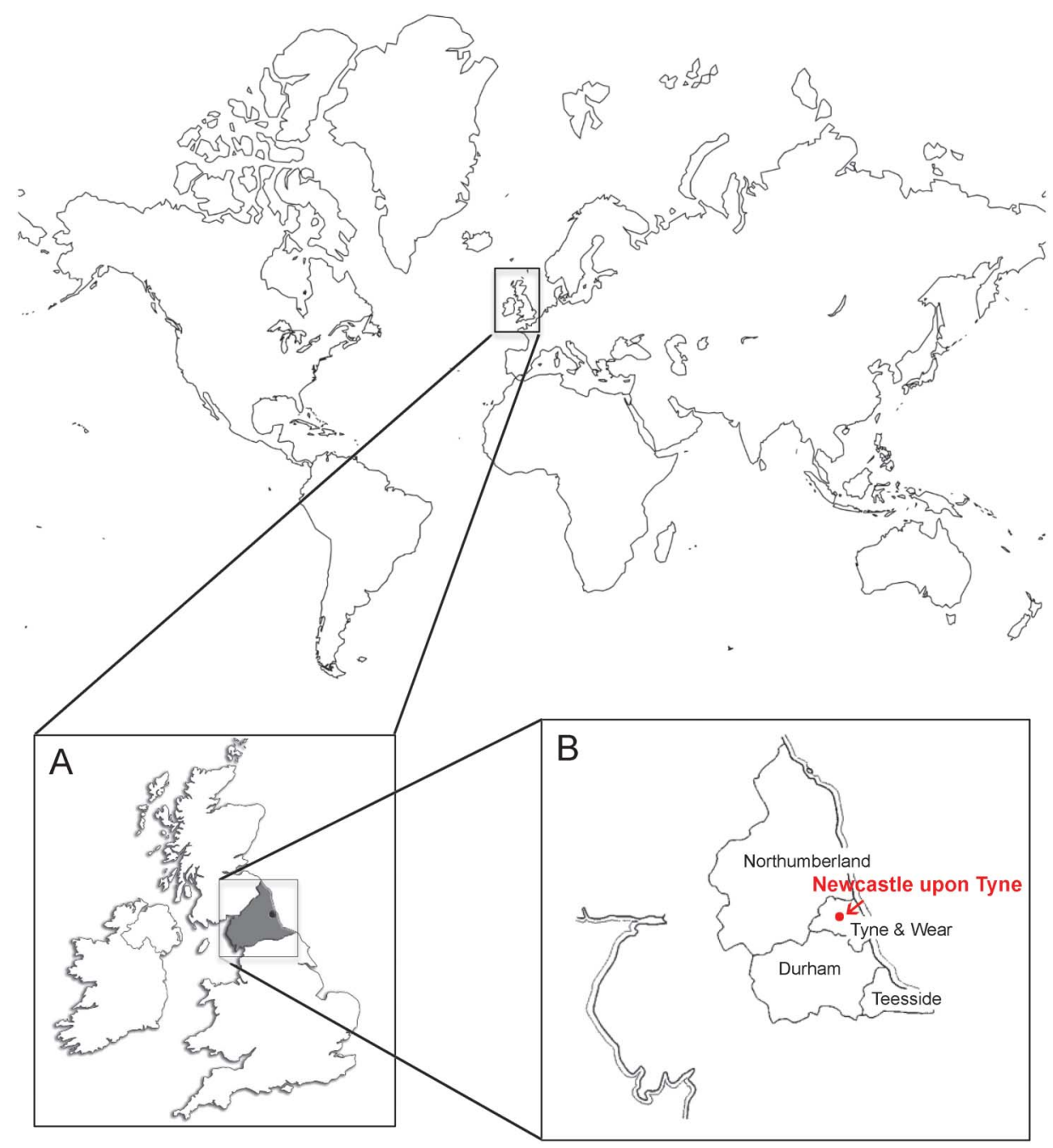

Map of the world showing the United Kingdom (A) and the North of England (shaded in A). (B) North of England region and Newcastle upon Tyne and the population regions specified in appendix e-1.

estimate from the Northern England neurogenetic database, an up-to-date census of patients with genetic conditions maintained by the Northern Genetics Service, which is based in Newcastle upon Tyne and serves the geographic region shown in the figure. Overall, the minimum point prevalence for neurogenetic disorders in the North of England was 90.9/100,000 (95\% CI 87.6-94.3). The specific studies contributing to this result are described below.

Inherited muscle disease. The point prevalence of all causes of genetic muscle disease was determined by Norwood et al. ${ }^{3}$ by a survey of a specialist muscle disease clinic in the North of England. From a clinic population of 1,100 patients registered with the Newcastle neuromuscular team, the combined point prevalence for all genetic muscle disease of 37.0/100,000 (95\% CI 34.8-39.2) was established. The 5 main conditions represented in the population were myotonic dystrophy with a point prevalence of
10.6/100,000 (95\% CI 9.6-11.6), dystrophinopathies at 8.5/100,000 (95\% CI 7.6-9.4), facioscapulohumeral muscular dystrophy of 3.9/100,000 (95\% CI 3.3-4.7), limb-girdle muscular dystrophy 2.3/ 100,000 (95\% CI 1.8-2.9), and spinal muscular atrophy 1.9/100,000 (95\% CI 1.4-2.4). Twelve further muscle disorders made up the remaining diagnoses including congenital muscular dystrophy with a point prevalence of $0.90 / 100,000$ (95\% CI $0.60-1.3)$ and 4 patients had X-linked EmeryDreifuss muscular dystrophy giving a point prevalence of 0.13 (95\% CI 0.04-0.34). ${ }^{3}$

The prevalence of GNE (glucosamine [UDP-Nacetyl]-2-epimerase/ $\mathrm{N}$-acetylmannosamine kinase) myopathy, a rare distal myopathy with inclusion bodies estimated under the category of "distal myopathies," ${ }^{3}$ was recently assessed separately in a Northern England cohort. ${ }^{4}$ Cases were identified from referral records to the Newcastle MRC 


\begin{tabular}{|c|c|c|c|c|c|}
\hline & Years of study & Cases (population) & Source of patients & Disorder & $\begin{array}{l}\text { Prevalence, per } 100,000 \\
(95 \% \mathrm{Cl})\end{array}$ \\
\hline Muscle disease & & & & & $37.0(34.8-39.2)$ \\
\hline \multirow[t]{7}{*}{ Norwood et al. ${ }^{3}$} & 2007 & $1,100(2,990,000)$ & Neuromuscular disease clinic & Myotonic dystrophy & $10.6(9.6-11.6)$ \\
\hline & & & & Dystrophinopathies & $8.5(7.6-9.4)$ \\
\hline & & & & FSHD & $3.9(3.3-4.7)$ \\
\hline & & & & LGMD & $2.3(1.8-2.9)$ \\
\hline & & & & SMA & $1.9(1.4-2.4)$ \\
\hline & & & & CMD & $0.90(0.60-1.3)$ \\
\hline & & & & EDMD-X & $0.13(0.04-0.34)$ \\
\hline Inherited neuropathies & & & & & $11.8(10.6-13.1)$ \\
\hline \multirow[t]{2}{*}{ Foley et al. ${ }^{5}$} & 2010 & $352(2,990,000)$ & $\begin{array}{l}\text { Clinical neurogenetic, clinical } \\
\text { neurophysiology, and molecular } \\
\text { diagnostic services }\end{array}$ & CMT disease & $9.8(8.7-11.0)$ \\
\hline & & & & HNPP & $2.0(1.5-2.5)$ \\
\hline Inherited ataxia & & & & & $5.8(4.9-6.9)$ \\
\hline \multirow[t]{2}{*}{ Craig et al. ${ }^{6}$} & 2001 & $26(2,516,500)$ & Regional neurogenetics clinic & SCA6 & $1.3(1.0-1.8)$ \\
\hline & & & & ADCA (estimated) & $5.2(4.3-6.1)$ \\
\hline Craig et al. ${ }^{7}$ & 2005 & $3(2,516,500)$ & Regional neurogenetics clinic & SCA17 & $0.12(0.00-0.35)$ \\
\hline Pfeffer et al. ${ }^{8}$ & 2011-2012 & $17(2,134,449)$ & Regional neurogenetics clinic & SPG7 & $0.80(0.00-1.28)$ \\
\hline Movement disorders & & & & & $18.3(8.3-34.6)$ \\
\hline Evans et al. ${ }^{9}$ & $1990-2010$ & $9(49,317)$ & $\begin{array}{l}\text { Electronic medical records from } \\
\text { national primary care database }\end{array}$ & Huntington disease & $18.3(8.3-34.6)$ \\
\hline Mitochondrial & & & & & $7.6(6.5-8.9)$ \\
\hline \multirow[t]{2}{*}{ Gorman et al. ${ }^{12}$} & $1990-2011$ & $163(2,134,449)$ & $\begin{array}{l}\text { Mitochondrial disease clinic and } \\
\text { genetic diagnostic service }\end{array}$ & $\begin{array}{l}\text { mito disease (non- } \\
\text { LHON) }\end{array}$ & $7.6(6.5-8.9)$ \\
\hline & & & & $\begin{array}{l}\text { mito mutations (non- } \\
\text { LHON) }\end{array}$ & $7.8(6.8-9.0)$ \\
\hline Inherited optic neuropathies & & & & & $7.8(6.8-8.8)$ \\
\hline \multirow[t]{2}{*}{ Gorman et al. ${ }^{12}$} & $1990-2011$ & $78(2,134,449)$ & $\begin{array}{l}\text { Mitochondrial disease clinic and } \\
\text { genetic diagnostic service }\end{array}$ & LHON disease & $3.7(2.9-4.6)$ \\
\hline & & & & LHON mutations & $4.4(3.7-5.3)$ \\
\hline $\begin{array}{l}\text { Yu-Wai-Man and } \\
\text { Chinnery }^{14}\end{array}$ & $1990-2013$ & $126(3,061,400)$ & $\begin{array}{l}\text { Mitochondrial genetic diagnostic } \\
\text { service }\end{array}$ & DOA & $4.1(3.4-4.9)$ \\
\hline $\begin{array}{l}\text { Hereditary spastic } \\
\text { paraparesis }\end{array}$ & & & & & $2.8(2.2-3.6)$ \\
\hline Unpublished & 2014 & $74(2,610,000)$ & Regional neurogenetics clinic & Sporadic, AD, AR & $2.8(2.2-3.6)$ \\
\hline Total & & & & & $90.9(87.6-94.3)$ \\
\hline
\end{tabular}

Abbreviations: $A D=$ autosomal dominant; $A D C A=$ autosomal dominant cerebellar ataxia; $A R=$ autosomal recessive; $C l=$ confidence interval; $C M D=$ congenital muscular dystrophy; CMT = Charcot-Marie-Tooth; DOA = dominant optic atrophy; EDMD = Emery-Dreifuss Muscular Dystrophy; FSHD = facioscapulohumeral dystrophy; HNPP = hereditary neuropathy with liability to pressure palsy; LGMD = limb-girdle muscular dystrophy; LHON = Leber hereditary optic neuropathy; mito = mitochondrial; SCA = spinocerebellar ataxia; SMA = spinal muscular atrophy.

All studies contain North of England (UK) data. The total prevalence estimate (with $95 \% \mathrm{Cl}$ ) was derived using the median North of England population estimate from the time period of all included studies.

Neuromuscular GNE diagnostic service, also based in the Northern Genetic Service. Genetics testing became available in 2010, after which the center received 87 referrals-64\% from England, 13\% Scotland, 14\% from Northern Ireland, and the remaining referrals from abroad. Twenty-six cases of GNE myopathy were identified, 7 of these from England (3 from Northern England, 4 from Southern England), 10 from Scotland, 8 from Northern Ireland, and 1 from the Republic of Ireland. Using these population estimates, a point prevalence of GNE myopathy in Northern England can be calculated as 1/million (95\% CI 0.0-2.9) and for the UK as $0.4 /$ million (95\% CI 0.0-0.6).

Inherited neuropathies. The most recent UK epidemiologic study of inherited neuropathies was published 
in 2012. ${ }^{5}$ The authors calculated the point prevalence of Charcot-Marie-Tooth (CMT) disease and hereditary neuropathy with liability to pressure palsy (HNPP) in a Northern England cohort using 3 databases, identifying cases using clinical, molecular diagnostic, and electrophysiologic criteria. From these, 352 individuals from 275 families were identified with a clinical diagnosis of CMT disease or HNPP. A minimum prevalence of CMT disease in the Northern region was estimated at 9.8/100,000 (95\% CI 8.7-11.0) and for HNPP at 2.0/100,000 (95\% CI 1.5-2.5), giving a combined minimum prevalence of 11.8/100,000 (95\% CI 10.6-13.1).

Inherited ataxias. Two studies in the North of England region calculated point prevalence of $S C A G$ and SCA17 mutations, which both cause autosomal dominant cerebellar ataxia (ADCA). The first of these evaluated the prevalence of $S C A 6$ mutations, ${ }^{6}$ which lead to an adult-onset progressive syndrome of ataxia, dysarthria, and nystagmus. Twenty-six cases heterozygous for the CAG repeats were identified from 16 genealogically distinct families. Using their data, a minimum prevalence of ADCA due to $S C A G$ can be estimated as 1.3/100,000 (95\% CI 1.0-1.8) and in adults aged 45 years or older as 3.2/100,000 (95\% CI 2.1-4.3). Because SCA6 mutations account for approximately $20 \%$ of ADCA in the region, the minimum prevalence of $\mathrm{ADCA}$ in the general population can be calculated as 5.2/100,000 (95\% CI 4.3-6.1). The same group conducted a further study assessing the prevalence of $\operatorname{SCA}_{17}{ }^{7}$ a dominantly inherited ataxia with extrapyramidal features and dementia presenting with a Huntington disease (HD)-like phenotype. Ninety families with suspected HD and 192 families with undiagnosed ataxia were included and screened for SCA17 mutations. Two of the 192 patients with undiagnosed ataxia, but none of the HD-like patients, were found to have (CAG/CAA) expansions larger than the control range. Using these data, a minimum prevalence of SCA17 was estimated as $0.12 / 100,000$ (95\% CI $0.00-0.35$ ). There were no UK studies specifically studying the prevalence of autosomal recessive ataxia, apart from one focused on SPG7 in North East England, ${ }^{8}$ which reported a prevalence of 0.80/100,000 (95\% CI $0.00-0.13)$.

Movement disorders. The prevalence of HD in a UK cohort was estimated using the UK's General Practice research database, the world's largest computerized database of primary care medical records. ${ }^{9}$ Patients older than 21 years with a diagnosis of HD were included $(\mathrm{n}=1136)$, and prevalence rates were calculated annually between 1990 and 2010. The prevalence of HD increased considerably between with this period, with a prevalence of 5.4/100,000 (95\% CI 3.8-7.5) in 1990 up to a prevalence of $12.3 /$ 100,000 (95\% CI 11.2-13.5) in 2010. These increased rates over time were predominantly represented in patients older than 60 years, whereby a prevalence in the 60 to 69 age group of $12.6 /$ 100,000 (95\% CI 9.1-17.1) in 1990 rose to $24.2 /$ 100,000 (95\% CI 21.1-27.5) in 2010 and in the $70+$ group a prevalence of 7.2/100,000 (95\% CI $4.8-10.4)$ in 1990 rose to $15.6 / 100,000$ (95\% CI 13.2-18.3) in 2010. Results were further analyzed on a regional basis showing that the North East of England and Scotland had the highest prevalence rates (18.3/100,000: 95\% CI 8.4-34.6 and 16.1/ 100,000: 95\% CI 10.8-22.9, respectively) while the lowest rates were found in London (5.4/ 100,000: 95\% CI 3.0-8.8).

Mitochondrial disease. The prevalence of mitochondrial disease was initially estimated in $2000,{ }^{10}$ and subsequently revised, ${ }^{11,12}$ based on referrals to a national diagnostic service for rare mitochondrial diseases in Newcastle upon Tyne in the North of England. The minimum prevalence of mitochondrial disease was established through molecular genetics testing for mitochondrial DNA (mtDNA) point mutations and deletions, and nuclear-genetic causes of mitochondrial disease in adults (defined as older than 16 years; SPG 7 and $O P A 1$ are included in the ataxia and inherited optic neuropathy sections of this report, respectively). ${ }^{12}$ Both adults and children were included to establish those at risk of mitochondrial disease. By excluding mtDNA mutations that cause Leber hereditary optic neuropathy (LHON, considered separately in the section "Inherited optic neuropathies" below), the minimum prevalence of non-LHON mitochondrial disease mutations in the population was calculated as 7.8/100,000 (95\% CI 6.8-9.0) and the minimum prevalence of nonLHON mitochondrial disease as 7.6/100,000 (95\% CI 6.5-8.9).

Inherited optic neuropathies. The 2 principal inherited optic neuropathies are LHON and autosomal dominant optic atrophy (DOA).

The prevalence of LHON was established through the prospective mtDNA genetic testing of patients with unexplained visual failure or suspected LHON in the Northern Genetic Service over a 21-year period (January 1990 to May 2011). ${ }^{12}$ Within this population, the prevalence of LHON was calculated as 3.7/ 100,000 (95\% CI 2.9-4.6), while the prevalence of mtDNA LHON mutations, representing those "at risk" within the population, was 4.4/100,000 (95\% CI 3.7-5.3).

The same center previously established the prevalence of DOA using North of England neurogenetic 
and ophthalmology clinical databases. ${ }^{13}$ Seventy-six patients from 22 families were identified with a clinical diagnosis of DOA, and OPA1 gene sequencing was performed on this group. Those found to be negative for this were further screened for OPA1 rearrangements and $O P A 3$ mutations. The majority $(14 / 22,63.6 \%)$ of families with DOA carried OPA1 mutations while $O P A 1$ rearrangements were only found in one family and no OPA3 mutations were detected in the study cohort. The calculated point prevalence estimate from this data for clinically determined DOA was $2.9 / 100,000$ (95\% CI 2.3$3.5)$ with the point prevalence of molecularly confirmed OPA1-positive DOA as 2.1/100,000 (95\% CI 1.6-2.7). A recent update from the same group included a further 8 OPA1-positive and 5 OPA1negative families resulting in a revised point prevalence estimate for DOA of 4.1/100,000 (95\% CI $3.7-4.5) .{ }^{14}$

Hereditary spastic paraparesis. We found no published UK epidemiologic data on the prevalence of HSP. We identified cases in the North of England using the Northern Genetics Service database to identify patients with suspected and genetically confirmed HSP. All patients had brain and spinal cord imaging to exclude a structural or inflammatory cause for the spastic paraparesis, and all had normal CSF examination. From a population of 2.61 million (mid-2013 estimate) in the North East region, 176 individual cases from 55 genealogically distinct families with clinical HSP were identified. Of this group, 74 cases (44.3\%) had a confirmed genetic diagnosis giving a minimum point prevalence of confirmed HSP of 2.8/100,000 (95\% CI 2.2-3.6). This did not include patients with $S P G 7$ who were identified through their ataxic presentation and were included in the ataxia section above.

DISCUSSION Here we show that approximately 1 in 1,100 of the general population is directly affected by a "single gene" neurologic disorder. This figure is likely to be an underestimate for several reasons. First, most of the studies we included had ascertained cases through hospital referrals, and not by systematically investigating a community-based cohort. This approach introduces a bias toward younger, more highly motivated individuals who seek specialist advice about a rare diagnosis. Older patients may be less inclined to pursue a precise diagnosis in a specialist center, given that there may be little hope of a cure. Many of the disorders described here have an age-related penetrance, so the underascertainment of older individuals is likely. Prospective communitybased studies usually yield higher prevalence figures, but are particularly challenging for rare diseases because of the very large sample size required to reliably estimate the prevalence. ${ }^{15}$ Second, some of the studies did not incorporate comprehensive genetic testing, raising the possibility that some of the cases were misdiagnosed as a noninherited disorder because there was no family history, and missed altogether. Family history is not a reliable guide to monogenic disease because a positive family history depends on the degree of relative affected, ${ }^{16}$ and even high penetrance mutations frequently present without a family history. ${ }^{17}$ Finally, it is also important to note that here we describe the results of several different studies performed at different time points. Most, but not all, of the studies were performed in the same geographic region but had subtly different forms of case ascertainment and encompassed different age groups (table).

Could our results be an overestimate? This is unlikely because most of the studies we included were performed in the North of England, which has a welldefined outbred stable population of largely white European extraction. ${ }^{1}$ Given the limited consanguinity, it is unlikely that the prevalence estimates of recessive neurogenetic disorders are unusually high. When taken together, our findings are therefore likely to have broader relevance for other similar populations. When compared with prevalence data from studies worldwide, most of our estimates fit comfortably within previously delineated ranges: an earlier estimate of the prevalence of inherited muscle disease was 1 in 3,000 or $33.3 / 100,000,{ }^{18}$ and a recent review has estimated the worldwide prevalence of HSP and ADCA as 0.1-9.6/100,000 and 0.7-5.6/100,000, respectively. ${ }^{19}$ Prevalence estimates for sporadic idiopathic cerebellar ataxia and autosomal recessive cerebellar ataxia (ARCA) were not obtainable for our region but can be estimated from a study in South Wales, UK, a region with a stable population and similar demographic. ${ }^{20}$ From a group of 76 cases with late-onset cerebellar ataxia identified from general practice, hospital and health authority databases, as well as through personal notification from consultant neurologists, 4 were classified as ARCA, giving a prevalence estimate of $0.53 / 100,000$ ( $95 \%$ CI $0-1.38$ ). We note, when comparing these data with the worldwide review, ${ }^{19}$ the prevalence estimate for ARCAs represents the lower end of a worldwide range spanning from 0.1 to $7.2 / 100,000$. As noted by the authors of the Welsh study ${ }^{20}$ this is likely attributable to methodologic limitations in case ascertainment as well as the challenge of classifying patients with an undetermined family history. It was further restricted in considering only "late-onset" cerebellar ataxia (symptom onset at age 18 years or older), which is likely to significantly underestimate the overall 
prevalence of ARCA. In a similar way, estimates of the prevalence of mitochondrial disorders ${ }^{10,12}$ did not include affected pediatric cases. In the age group younger than 16 years, the minimum prevalence of mitochondrial disorders has been estimate at 5.0/ 100,000 (95\% CI 4.0-6.2), ${ }^{21}$ indicating that, for these conditions, our quoted figures provide an underestimate. Likewise, with the almost exponential increase in disease gene discovery, the number of "single gene" neurogenetic disorders is on the increase, ${ }^{22}$ further emphasizing that the figures we report here are likely to be a conservative underestimate.

We deliberately did not include genetic forms of common neurodegenerative diseases in our review because of the difficulty in diagnosing inherited forms of the disorder, which may be clinically indistinguishable from sporadic cases. However, using UK prevalence data for the principal neurodegenerative disorders Alzheimer disease (UK prevalence 1,100/ 100,000 , of which $\sim 110 / 100,000[\sim 1 \%]$ are monogenic ${ }^{23}$ ), Parkinson disease (UK prevalence 300/ 100,000 , of which $\sim 30 / 100,000$ [ 10\%] are monogenic $^{24,25}$ ), motor neuron disease (ALS, UK prevalence 6/100,000, of which $\sim 0.3 / 100,000$ [ 5\%] are monogenic $^{26}$ ), and DYT1 dystonia (prevalence $\sim 51$ $100,000^{27}$ ), the combined overall minimum prevalence of neurogenetic disorders increases to $\sim 234$ / 100,000 , or at least 1 in 423 of the UK population. This figure does not include sporadic neurodegenerative diseases with a complex genetic architecture involving many different genetic loci, such as $A P O E$, which has a moderately strong influence on the risk of developing Alzheimer disease. It also cannot include genetic forms of neurodegenerative disease due to hitherto unknown genes. This is important to recognize, given the recent unexpected finding that hexanucleotide repeat expansions in C9ORF72 cause a substantial proportion of cases of ALS and other neurodegenerative diseases. ${ }^{28,29}$ For these reasons, even the prevalence of 1 in 423 is likely to be an underestimate.

These findings have major implications. For example, the average UK primary care practice will have at least 16 patients with single gene neurogenetic disorders on their records ${ }^{30}$ and with an aging population, these figures are likely to increase. Moreover, a UK neurologist will have on average 80 patients with a neurogenetic disorder within their referral area. ${ }^{31}$ The majority of the disorders discussed here have no treatment and cause progressive disability, often over several decades. The effect on families and medical and social services will be substantial. Second, our estimates do not account for the impact of the genetic diagnoses on at-risk family members, who may request genetic counseling and prenatal and preimplantation diagnosis to prevent recurrence. Finally, with the mainstream introduction of exome and whole genome sequencing in clinical practice, the number of unexpected predictive tests will also increase, placing even greater strain on clinical service provision, and emphasizing the need to develop treatments that can slow down or prevent these disorders.

\section{AUTHOR CONTRIBUTIONS}

David Bargiela: drafting/revising the manuscript, study concept or design, analysis or interpretation of data, accepts responsibility for conduct of research and will give final approval, acquisition of data, statistical analysis. Patrick Yu-Wai-Man: drafting/revising the manuscript, analysis or interpretation of data, accepts responsibility for conduct of research and will give final approval, acquisition of data. Michael Keogh: drafting/ revising the manuscript, analysis or interpretation of data, accepts responsibility for conduct of research and will give final approval. Rita Horvath: drafting/revising the manuscript, study concept or design, analysis or interpretation of data, accepts responsibility for conduct of research and will give final approval, acquisition of data. Patrick Chinnery: drafting/ revising the manuscript, study concept or design, analysis or interpretation of data, accepts responsibility for conduct of research and will give final approval, study supervision.

\section{STUDY FUNDING}

P.F.C. is an Honorary Consultant Neurologist at Newcastle upon Tyne Foundation Hospitals NHS Trust, is a Wellcome Trust Senior Fellow in Clinical Science (101876/Z/13/Z), and a UK NIHR Senior Investigator. P.F.C. receives additional support from the Wellcome Trust Centre for Mitochondrial Research (096919Z/11/Z), the Medical Research Council (UK) Centre for Translational Muscle Disease research (G0601943), EU FP7 TIRCON, and the National Institute for Health Research (NIHR) Newcastle Biomedical Research Centre based at Newcastle upon Tyne Hospitals NHS Foundation Trust and Newcastle University. The views expressed are those of the author(s) and not necessarily those of the NHS, the NIHR, or the Department of Health.

\section{DISCLOSURE}

The authors report no disclosures relevant to the manuscript. Go to Neurology.org for full disclosures.

Received February 5, 2015. Accepted in final form April 28, 2015.

\section{REFERENCES}

1. Vanderpump MP, Tunbridge WM, French JM, et al. The incidence of thyroid disorders in the community: a twenty-year follow-up of the Whickham Survey. Clin Endocrinol 1995;43:55-68.

2. Office for National Statistics. Population estimates for UK, England and Wales, Scotland and Northern Ireland. Available at: http://www.ons.gov.uk/ons/publications/allreleases.html?definition $=\mathrm{tcm} \% 3 \mathrm{~A} 77-22371 . \quad$ Accessed January 22, 2015.

3. Norwood FL, Harling C, Chinnery PF, Eagle M, Bushby K, Straub V. Prevalence of genetic muscle disease in Northern England: in-depth analysis of a muscle clinic population. Brain 2009;132:3175-3186.

4. Chaouch A, Brennan KM, Hudson J, et al. Two recurrent mutations are associated with GNE myopathy in the North of Britain. J Neurol Neurosurg Psychiatry 2014; 85:1359-1365.

5. Foley C, Schofield I, Eglon G, Bailey G, Chinnery PF, Horvath R. Charcot-Marie-Tooth disease in Northern England. J Neurol Neurosurg Psychiatry 2012;83: 572-573. 
6. Craig K, Keers SM, Archibald K, Curtis A, Chinnery PF Molecular epidemiology of spinocerebellar ataxia type 6 . Ann Neurol 2004;55:752-755.

7. Craig K, Keers SM, Walls TJ, Curtis A, Chinnery PF. Minimum prevalence of spinocerebellar ataxia 17 in the North East of England. J Neurol Sci 2005;239:105-109.

8. Pfeffer G, Pyle A, Griffin H, et al. SPG7 mutations are a common cause of undiagnosed ataxia. Neurology 2015;84: 1174-1176.

9. Evans SJ, Douglas I, Rawlins MD, Wexler NS, Tabrizi SJ, Smeeth L. Prevalence of adult Huntington's disease in the UK based on diagnoses recorded in general practice records. J Neurol Neurosurg Psychiatry 2013;84:1156-1160.

10. Chinnery PF, Johnson MA, Wardell TM, et al. The epidemiology of pathogenic mitochondrial DNA mutations. Ann Neurol 2000;48:188-193.

11. Schaefer AM, McFarland R, Blakely EL, et al. Prevalence of mitochondrial DNA disease in adults. Ann Neurol 2008;63:35-39.

12. Gorman GS, Schaefer AM, Ng Y, et al. Prevalence of nuclear and mtDNA mutations related to adult mitochondrial disease. Ann Neurol 2015;77:753-759.

13. Yu-Wai-Man P, Griffiths PG, Burke A, et al. The prevalence and natural history of dominant optic atrophy due to OPA1 mutations. Ophthalmology 2010;117:1538-1546.e1.

14. Yu-Wai-Man P, Chinnery PF. Dominant optic atrophy: novel OPA1 mutations and revised prevalence estimates. Ophthalmology 2013;120:1712-1712.e1.

15. Elashoff J, Lemeshow S. Sample size determination in epidemiologic studies. In: Ahrens W, Pigeot I, editors. Handbook of Epidemiology. Berlin: Springer; 2005:559-594.

16. Byrne S, Elamin M, Bede P, Hardiman O. Absence of consensus in diagnostic criteria for familial neurodegenerative diseases. J Neurol Neurosurg Psychiatry 2012;83: 365-367.

17. Al-Chalabi A, Lewis CM. Modelling the effects of penetrance and family size on rates of sporadic and familial disease. Hum Hered 2011;71:281-288.

18. Emery AE. Population frequencies of inherited neuromuscular diseases: a world survey. Neuromuscul Disord 1991; 1:19-29.

19. Ruano L, Melo C, Silva MC, Coutinho P. The global epidemiology of hereditary ataxia and spastic paraplegia: a systematic review of prevalence studies. Neuroepidemiology 2014;42:174-183.

20. Muzaimi MB, Thomas J, Palmer-Smith S, et al. Population based study of late onset cerebellar ataxia in south east Wales. J Neurol Neurosurg Psychiatry 2004;75: 1129-1134.

21. Skladal D, Halliday J, Thorburn DR. Minimum birth prevalence of mitochondrial respiratory chain disorders in children. Brain 2003;126:1905-1912.

22. Singleton $\mathrm{AB}$. Exome sequencing: a transformative technology. Lancet Neurol 2011;10:942-946.

23. Campion D, Dumanchin C, Hannequin D, et al. Earlyonset autosomal dominant Alzheimer disease: prevalence, genetic heterogeneity, and mutation spectrum. Am J Hum Genet 1999;65:664-670.

24. de Lau LM, Breteler MM. Epidemiology of Parkinson's disease. Lancet Neurol 2006;5:525-535.

25. Nussbaum RL, Ellis CE. Alzheimer's disease and Parkinson's disease. N Engl J Med 2003;348:1356-1364.

26. Byrne S, Walsh C, Lynch C, et al. Rate of familial amyotrophic lateral sclerosis: a systematic review and metaanalysis. J Neurol Neurosurg Psychiatry 2011;82: 623-627.

27. Frédéric M, Lucarz E, Monino C, et al. First determination of the incidence of the unique TOR1A gene mutation, c.907delGAG, in a Mediterranean population. Mov Disord 2007;22:884-888.

28. Renton AE, Majounie E, Waite A, et al. A hexanucleotide repeat expansion in C9ORF72 is the cause of chromosome 9p21-linked ALS-FTD. Neuron 2011;72:257-268.

29. Majounie E, Renton AE, Mok K, et al. Frequency of the C9orf72 hexanucleotide repeat expansion in patients with amyotrophic lateral sclerosis and frontotemporal dementia: a cross-sectional study. Lancet Neurol 2012;11:323-330.

30. Health \& Social Care Information Centre. Number of Patients Registered at a GP Practice-April 2013: GP Registered Patients. Available at: http://www.hscic.gov. uk/catalogue/PUB10952/gp-reg-patients-04-2013. csv2013. Accessed January 22, 2015.

31. Association of British Neurologists. ABN Annual Report [online]. Available at: http://www.theabn.org/media/ AnnualReport2013finalprint.pdf. Accessed January 22, 2015.

\section{Save These Dates for AAN CME Opportunities!}

Mark these dates on your calendar for exciting continuing education conferences by the American Academy of Neurology. Learn more at AAN.com/conferences.

\section{AAN Fall Conference}

- October 16-18, 2015, Las Vegas, NV, The Cosmopolitan of Las Vegas

\section{Breakthroughs in Neurology Conference}

- January 15-18, 2016, Orlando, FL, Omni Orlando Resort at ChampionsGate

\section{AAN Annual Meeting}

- April 15-21, 2016, Vancouver, BC, Canada, Vancouver Convention Centre 


\section{Neurology}

\section{Prevalence of neurogenetic disorders in the North of England \\ David Bargiela, Patrick Yu-Wai-Man, Michael Keogh, et al.}

Neurology 2015;85;1195-1201 Published Online before print September 4, 2015

DOI 10.1212/WNL.0000000000001995

This information is current as of September 4, 2015

\section{Updated Information \& Services}

Supplementary Material

References

Citations

Subspecialty Collections

Permissions \& Licensing

Reprints including high resolution figures, can be found at: http://n.neurology.org/content/85/14/1195.full

Supplementary material can be found at: http://n.neurology.org/content/suppl/2015/09/04/WNL.0000000000001 995.DC1

http://n.neurology.org/content/suppl/2015/09/04/WNL.0000000000001 995.DC2

This article cites 27 articles, 7 of which you can access for free at: http://n.neurology.org/content/85/14/1195.full\#ref-list-1

This article has been cited by 2 HighWire-hosted articles: http://n.neurology.org/content/85/14/1195.full\#\#otherarticles

This article, along with others on similar topics, appears in the following collection(s):

All epidemiology

http://n.neurology.org/cgi/collection/all_epidemiology

All Genetics

http://n.neurology.org/cgi/collection/all_genetics

Prevalence studies

http://n.neurology.org/cgi/collection/prevalence_studies

Information about reproducing this article in parts (figures,tables) or in its entirety can be found online at:

http://www.neurology.org/about/about_the_journal\#permissions

Information about ordering reprints can be found online:

http://n.neurology.org/subscribers/advertise

Neurology ${ }^{\circledR}$ is the official journal of the American Academy of Neurology. Published continuously since 1951, it is now a weekly with 48 issues per year. Copyright @ 2015 American Academy of Neurology. All rights reserved. Print ISSN: 0028-3878. Online ISSN: 1526-632X.

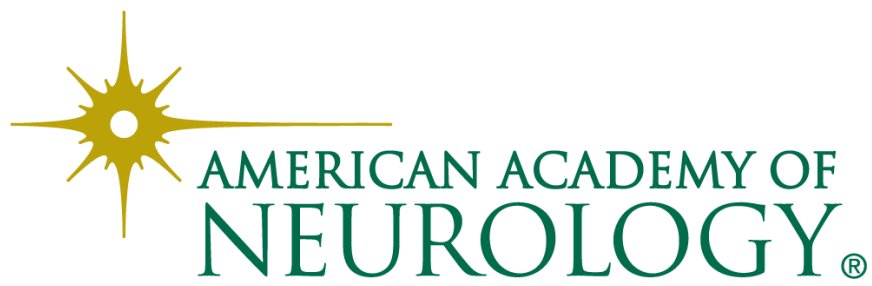

